\title{
PENGARUH KUALITAS LAYANAN TERHADAP KEPUASAN KONSUMEN MENGGUNAKAN JASA "RUMAH LAUNDRY" DI KECAMATAN PALU SELATAN
}

\author{
VERA NINGSIH \\ ROSIDA P. ADAM \\ YOBERTH KORNELIUS \\ Jurusan Manajemen, Fakultas Ekonomi, Universitas Tadulako \\ Email:veraaperra02@gmail.com
}

\begin{abstract}
The purpose of this study is to determine the influence of quality of service that consists of physical evidence (X1), empathy (X2), reliability (X3), responsiveness (X4) and assurance (X5) on consumer satisfaction using services "Home Laundry" in South Palu Sub-district, both simultaneously and partially. The type of study is causal-descriptive. The population consists of all consumers who use the services of "Home Laundry" in South Palu Sub-district. Sampling technique is purposive sampling with a sample size of 60 people. The analytical tool is multiple linear regressions analysis. Based on the results of multiple linear regression analysis show that the quality of service consists of physical evidence (X1), empathy (X2), reliability (X3), responsiveness (X4) and assurance (X5) simultaneously have significant influence on consumers' satisfaction in using the services of "Home Laundry" in South Palu, with significant values of 0.000>0.05. Partial test finds that the quality of service consists of physical evidence $(X 1)=0.011$, empathy $(X 2)=0.001$, reliability $(X 3)=0.001$, responsiveness $(X 4)=0.000$ and assurance $(X 5)=0.010$ significantly have partial influence on customer satisfaction in using the services of "Home Laundry" in South Palu Sub-district.
\end{abstract}

Keywords: service quality, customer satisfaction.

\section{Abstrak}

Tujuan dari penelitian ini adalah untuk mengetahui pengaruh kualitas pelayanan yang terdiri dari bukti fisik (X1), empati (X2), reliabilitas (X3), responsiveness (X4) dan assurance (X5) terhadap kepuasan konsumen dengan menggunakan layanan "Rumah Laundry "di Kecamatan Palu Selatan, baik secara simultan maupun parsial. Jenis penelitiannya bersifat kausal-deskriptif. Populasi terdiri dari semua konsumen yang menggunakan layanan "Binatu Rumah" di Kecamatan Palu Selatan. Teknik pengambilan sampel adalah purposive sampling dengan ukuran sampel 60 orang. Alat analisisnya adalah analisis regresi linier berganda. Berdasarkan hasil analisis regresi linier berganda menunjukkan bahwa kualitas pelayanan terdiri dari bukti fisik (X1), empati (X2), reliabilitas (X3), daya tanggap (X4) dan jaminan (X5) secara simultan berpengaruh signifikan terhadap kepuasan konsumen dalam menggunakan layanan di Rumah Laundry di Palu Selatan, dengan nilai signifikan 0,000>0,05. Uji parsial menemukan bahwa kualitas layanan terdiri dari bukti fisik $(\mathrm{X} 1)=0,011$, empati $(X 2)=0,001$, reliabilitas $(X 3)=0,001$, responsiveness $(X 4)=0,000$ dan jaminan $(X 5)=0,010$ berpengaruh secara signifikan terhadap kepuasan pelanggan dalam menggunakan layanan "Rumah Laundry" di Kecamatan Palu Selatan

Kata Kunci: kualitas pelayanan, kepuasan konsumen.

\section{PENDAHULUAN}

\section{Latar Belakang Penelitian}

Peningkatan kebutuhan manusia pada sektor ekonomi memberikan dampak semakin banyaknya para pengusaha yang membuka jenis usaha baru, khususnya usaha yang berbentuk jasa. Salah satu industri jasa yang berkembang pada beberapa tahun terakhir ini, adalah usaha jasa laundry. Laundry adalah fasilitas di mana pakaian dicuci dan dikeringkan Dengan demikian, usaha laundry dapat dikategorikan sebagai bentuk usaha jasa pelayanan pencucian berupa pakaian dan jenisnya yang digunakan sehari-hari. 
Sebagai salah satu usaha laundry yang telah dikenal memiliki keunggulan tentunya Rumah Laundry telah melewati tahap pertumbuhan dengan sangat baik hal ini dibuktikan berdasarkan data pelanggan yang tercantum pada Gambar 1 berikut:

\section{Data Pelanggan "Rumah Laundry" Tahun 2015}

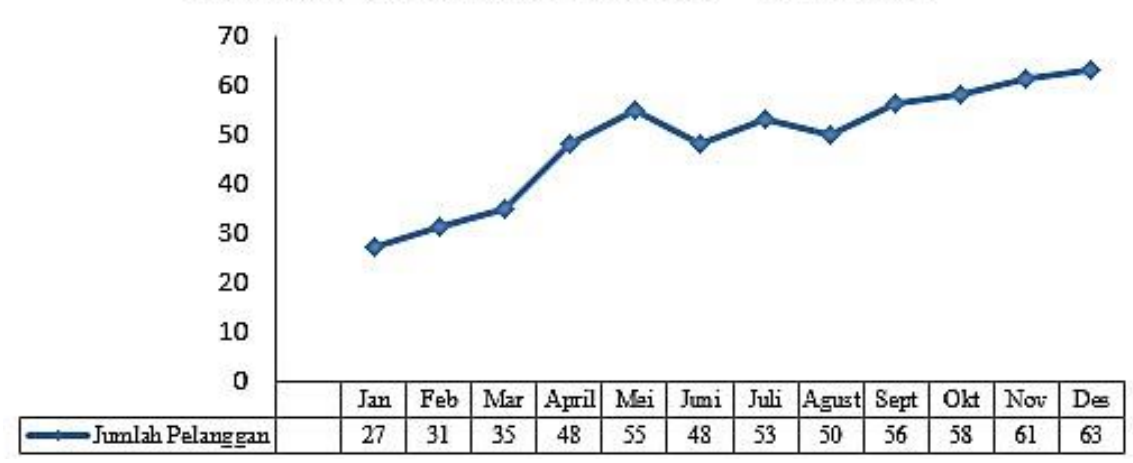

Sumber: Data Pelanggan Rumah Laundry di Kecamatan Palu Selatan

Gambar 1.

Jumlah Pelanggan/Konsumen Yang Menggunakan Jasa "Rumah Laundry" di Kecamatan Palu Selatan

\section{Permasalahan Penelitian}

Berdasarkan latar belakang yang telah diuraikan diatas, maka penulis menetapkan rumusan masalah sebagai berikut:

1. Apakah kualitas pelayanan yang terdiri atas: bukti fisik (tangibles), empati (emphaty), kehandalan (realibility), daya tanggap (responsiveness), jaminan (assurancce), secara bersamasama berpengaruh signifikan terhadap kepuasan konsumen menggunakan jasa "Rumah Laundry" di Kecamatan Palu Selatan?

2. Apakah variabel bukti fisik (tangibles), berpengaruh signifikan terhadap kepuasan konsumen menggunakan jasa "Rumah Laundry" di Kecamatan Palu Selatan?

3. Apakah variabel empati (empathy), berpengaruh signifikan terhadap kepuasan konsumen menggunakan jasa "Rumah Laundry" di Kecamatan Palu Selatan?

4. Apakah variabel kehandalan (realibility), berpengaruh signifikan terhadap kepuasan konsumen menggunakan jasa "Rumah Laundry" di Kecamatan Palu Selatan?

5. Apakah variabel daya tanggap (responsiveness), berpengaruh signifikan terhadap kepuasan konsumen menggunakan jasa "Rumah Laundry" di Kecamatan Palu Selatan?

6. Apakah variabel jaminan (assurance), berpengaruh signifikan terhadap kepuasan konsumen menggunakan jasa "Rumah Laundry" di Kecamatan Palu Selatan?

\section{Tujuan Penelitian}

Tujuan dilakukannya penelitian ini, adalah sebagai berikut:

1. Untuk mengetahui variabel kualitas layanan, yang terdiri dari: bukti fisik (tangibles), empati (emphaty), kehandalan (realibility), daya tanggap (responsiveness), jaminan (assurancce) terhadap kepuasan konsumen menggunakan jasa Rumah Laundry di Kecamatan Palu Selatan.

2. Untuk mengetahui pengaruh variabel bukti fisik (tangibles), terhadap kepuasan konsumen menggunakan jasa Rumah Laundry di Kecamatan Palu Selatan.

3. Untuk mengetahui pengaruh variabel empati (empathy), terhadap kepuasan konsumen menggunakan jasa Rumah Laundry di Kecamatan Palu Selatan.

4. Untuk mengetahui pengaruh variabel kehandalan (reliability), terhadap kepuasan konsumen menggunakan jasa Rumah Laundry di Kecamatan Palu Selatan.

5. Untuk mengetahui pengaruh variabel daya tanggap (responsiveness), terhadap kepuasan konsumen menggunakan jasa Rumah Laundry di Kecamatan Palu Selatan.

6. Untuk mengetahui pengaruh variabel jaminan (assurance), terhadap kepuasan konsumen menggunakan jasa Rumah Laundry di Kecamatan Palu Selatan. 


\section{KAJIAN LITERATUR DAN PENGEMBANGAN HIPOTESIS Kualitas Layanan}

Kualitas pelayanan menjadi suatu keharusan yang harus dilakukan perusahaan agar mampu bertahan dan tetap mendapat kepercayaan pelanggan. Pola konsumsi dan gaya hidup pelanggan menuntut perusahaan mampu memberikan pelayanan yang berkualitas. Rendahnya Kualitas akan menempatkan perusahaan pada kerugian kompetitif, berpotensi mengusir pelanggan yang tidak puas. Lovelock, dkk., (2010).

\section{Kepuasan Konsumen}

Kepuasan seseorang tergantung pada hubungan antara kinerja produk yang diperoleh dengan tingkat harapan pembeli yang bersangkutan. Bilamana kinerja yang diperoleh melebihi harapannya dia akan puas, sebaliknya bila kinerja produk yang diperoleh lebih rendah dari harapannya dia akan kecewa. Oleh karena itu, yang dimaksud dengan kepuasan adalah "Perasaan seseorang untuk menjadi senang atau kecewa sebagai hasil dari perbandingan antara kinerja produk yang dipersepsikan (hasil atau outcome) yang dihubungkan dengan harapannya". Bilamana kinerja produk lebih rendah dari harapan sebelumnya dia akan tidak puas atau kecewa. Bilamana kinerja produk sama dengan harapannya dia akan puas. Bilamana kinerja melebihi harapannya dia akan menjadi sangat puas.

\section{Hubungan Kualitas Layanan dan Kepuasan Konsumen}

Harapan, kebutuhan, dan kinerja pelayanan yang baik yang diberikan karyawan kepada konsumen merupakan bagian dari kepuasan pelanggan yang diyakini mempunyai peranan yang penting dalam menentukan kualitas jasa pelayanan. Pada dasarnya ada hubungan yang erat antara penentuan kualitas pelayanan dan kepuasan pelanggan. Kepuasan pelanggan adalah sejauh mana anggapan kinerja pelayanan yang diberikan karyawan memenuhi harapan, kebutuhan dari hasil kinerja yang menimbulkan reaksi emosional pada diri pelanggan, bila kualitas pelayanan yang diterima tidak sesuai dengan kebutuhan konsumen dan jauh dari harapan maka konsumn akan kecewa, sebaliknya bilayang diterima sama atau lebih dari kebutuhan dan harapannya maka konsumen akan puas. Kinerja pelayanan sesuai kebutuhan dan melebihi harapan, konsumen akan merasa sangat puas, gembira, dan senang.

\section{METODE PENELITIAN}

\section{Metode Pengumpulan Data}

Menurut Sugiyono (2013), pengumpulan data dapat dilakukan dalam berbagai setting, berbagai sumber, dan berbagai cara. Bila dilihat dari segi cara atau teknik pengumpulan data , maka teknik pengumpulan data dalam penelitian dapat dilakukan dengan kuesioner (angket) dan observasi (pengamatan).

\section{Kuesioner (Angket)}

Kuesioner merupakan teknik pengumpulan data yang dilakukan dengan cara memberi seperangkat pertanyaan atau pertanyaan tertulis kepada responden untuk dijawab. Kuesioner dapat berupa pertanyaan-pertanyaan tertutup atau terbuka, dapat diberikan kepada responden secara langsung atau dikirim melalui pos, atau internet.

\section{Kuesioner terstruktur}

Tingkat struktur dalam kuesioner adalah tingkat standarisasi yang diterapkan pada suatu kuesioner. Pada kuesioner terstruktur dimana pertanyaan-pertanyaan diajukan dengan susunan katakata dan urutan yang sama kepada semua responden ketika mengumpulkan data.

\section{Kuesioner Tak Terstruktur}

Kuesioner tak terstruktur dimana tujuan studi adalah jelas tetapi respon atau jawaban atas pertanyaan yang diajukan bersifat terbuka. 


\section{Observasi}

Sugiyono (2013) mengemukakan bahwa, observasi merupakan suatu proses yang kompleks, suatu proses yang tersusun dari pelbagai proses biologis dan psikhologis. Dua di antara yang terpenting adalah proses-proses pengamatan dan ingatan.

Ada beberapa bentuk observasi umum yang kita kenal yaitu:

\section{Observasi Berstruktur}

Pada observasi berstruktur, peneliti telah mengetahui aspek atau aktivitas apa yang akan diamati, yang relevan dengan masalah dan tujuan penelitian karena pada pengamatan, peneliti telah terlebih dulu mempersiapkan materi pengamatan dan instrumen yang akan digunakan. Observasi berstruktur, biasanya disebut juga dengan pengamatan sistematik, di mana peneliti secara lebih leluasa dapat menentukan perilaku apa yang akan diamati pada awal kegiatan pengamatan, agar permasalahan dapat dipecahkan.

\section{Observasi Tidak Berstruktur}

Observasi tidak berstruktur adalah observasi yang dilakukan tanpa menggunakan guide observasi. Dengan demikian pada observasi ini, pengamat harus mampu secara pribadi mengembangkan daya pengamatannya dalam mmengamati suatu objek. Pada observasi ini, yang terpenting adalah pengamat harus menguasai "ilmu" tentang objek secara umum dari apa yang hendak diamati. Dengan demikian, akan membantu lebih banyak pekerjaannya dalam mengamati objek yang baru itu.

\section{Populasi dan Sampel Populasi}

Populasi adalah wilayah generalisasi yang terdiri atas: obyek/subyek yang mempunyai kualitas dan karakteristik tertentu yang ditetapkan oleh peneliti untuk dipelajari. Jadi populasi bukan hanya orang, tetapi juga obyek dan benda-benda alam yang lain. Populasi juga bukan sekedar jumlah yang ada pada obyek/subyek yang dipelajari, tetapi meliputi seluruh karakteristik/sifat yang dimiliki oleh subyek atau obyek. Populasi dalam penelitian ini adalah konsumen Rumah Laundry yang berdomisili di Kota Palu.

\section{Teknik Penentuan Ukuran Sampel}

Dalam penelitian ini, penulis akan menggunakan teknik penarikan sampel purposive sampling yaitu penarikan sampel yang didasarkan pada kriteria tertentu. Mengingat jumlah populasi yang tidak di ketahui secara pasti, ukuran sampel dalam penelitian ini dilakukan dengan menggunakan pendekatan yang di rujuk dari Sugiyono, (2013) yang menyatakan bahwa untuk menentukan sampel dari populasi yang tidak diketahui adalah minimal 10 kali dari jumlah variabel yang diteliti (variabel independen + variabel depensen).

\section{Teknik Penarikan Sampel}

Jumlah variabel dalam penelitian ini adalah 6 yang terdiri dari 5 variabel independen (Tangibles, Reliability, Responsiveness, Assurance, Empathy) dan 1 variabel dependen (Kepuasan Konsumen). Berdasarkan pertimbangan tersebut maka penulis menetapkan jumlah sampel dengan ketentuan $10(5+1)$ variabel yaitu 60 responden, dengan demikian sampel dari penelitian ini adalah 60 orang.

Adapun kriteria responden yang dijadikan sampel dalam penelitian ini adalah sebagai berikut:

1. Berdomisili di Kota Palu.

2. Konsumen yang bersedia mengisi kuesioner.

3. Sudah pernah menjadi konsumen minimal 3 kali pada Rumah Laundry.

\section{Metode Analisis Data \\ Statistik Deskriptif}

Statistik deskriptif adalah statistik yang digunakan untuk menganalisa data dengan cara mendeskripsikan atau menggambarkan data yang telah terkumpul sebagaimana adanya tanpa bermaksud membuat kesimpulan yang berlaku untuk umum atau generalisasi Sugiyono (2013). Dalam 
penelitian ini, statistik deskriptif akan digunakan untuk menganalisa data dengan cara mendeskripsikan (menggambarkan) empiris data yang telah dikumpulkan dari responden melalui kuesioner penelitian dalam bentuk frekuensi tanggapan (jawaban) responden atas item-item pernyataan yang diajukan dari masing-masing variabel penelitian, serta nilai rata-rata (mean) variabel penelitian.

Sugiyono (2014) menyatakan bahwa untuk menginterprestasikan nilai mean dalam frekuensi variabel, maka dapat ditunjukkan dengan menggunakan skala interval sebagai berikut:

Skor Tertinggi : 5

Skor Terendah : 1

Rentang Skala $=\frac{\text { Skor Tertinggi-Skor Terendah }}{\text { Skor Tertinggi }}=\frac{5-1}{5}=0,8$

Sehingga diperoleh skala interval, sebagai berikut:

$$
\begin{array}{ll}
1,00-1,80 & =\text { Sangat Tidak Baik } \\
1,81-2,60 & =\text { Tidak Baik } \\
2,61-3,40 & =\text { Sedang } \\
3,41-4,20 & =\text { Baik } \\
4,21-5,00 & =\text { Sangat Baik }
\end{array}
$$

\section{Penelitian Karakteristik Responden}

Karakteristik responden ini menyangkut beberapa ciri yaitu jenis kelamin, umur, pekerjaan, tingkat pendidikan dan tingkat pendapatan berbulan konsumen yang menggunakan jasa Rumah Laundry.

\section{Karakteristik Responden Berdasarkan Jenis Kelamin}

Hasil penelitian yang dilakukan dengan jumlah 60 responden, diperoleh karakteristik responden berdasarkan jenis kelamin sebagaimana yang terlihat dalam Gambar 2 dibawah ini:

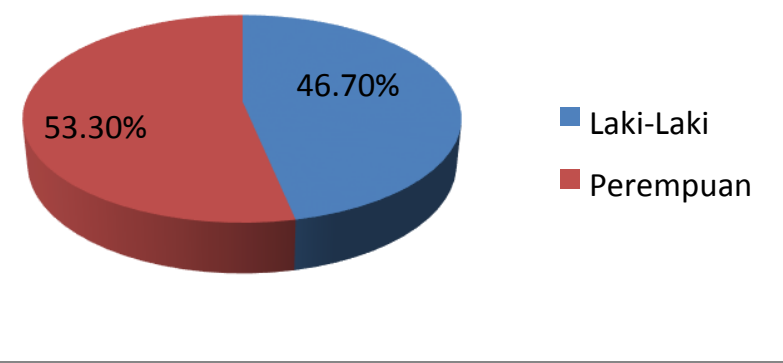

Gambar 2. Karakteristik Responden Berdasarkan Jenis Kelamin

Dari Gambar 2 diatas dapat diketahui bahwa sebanyak 32 orang $(53,3 \%)$ adalah berjenis kelamin perempuan, sedangkan sebanyak 28 orang $(46,7 \%)$ adalah berjenis kelamin laki-laki. Terlihat bahwa jumlah responden yang menggunakan jasa "Rumah Laundry" lebih banyak dipilih oleh konsumen berjenis kelamin perempuan. Hal ini di sebabkan karena sebagian besar konsumen Rumah Laundry berdasarkan koesioner, yang berjenis kelamin perempuan memiliki rutinitas sebagai pegawai swasta yang memiliki jam kerja yang tidak menentu sehingga mereka menggunakan jasa Rumah Laundry untuk meringankan pekerjaan rumah para konsumen tersebut

\section{Karakteristik Responden Berdasarkan Usia}

Hasil penelitian yang dilakukan dengan jumlah 60 responden, diperoleh karakteristik responden berdasarkan usia sebagaimana terlihat dalam Gambar 3 dibawah ini: 


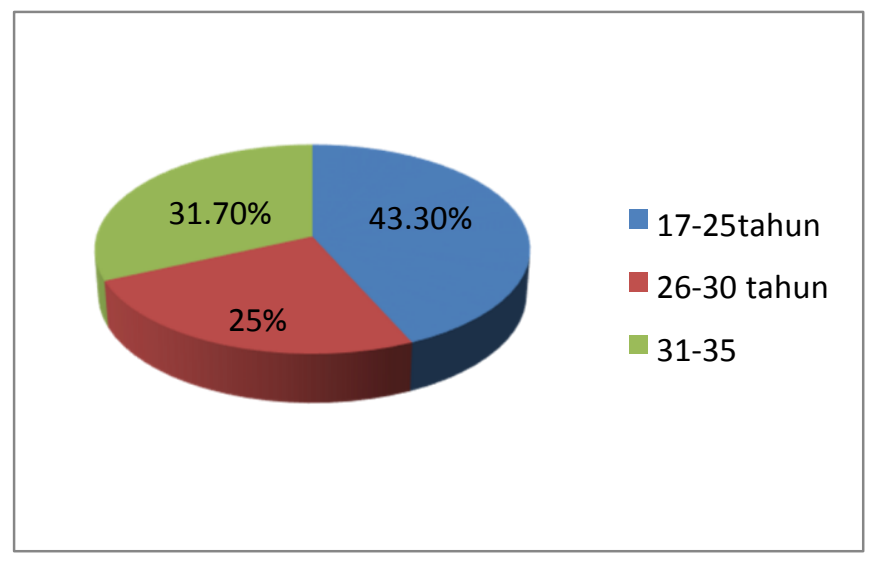

Gambar 3. Karakteristik Responden Berdasarkan Usia

Berdasarkan usia, dapat diketahui bahwa responden yang menggunakan jasa laundry di Rumah Laundry ini memiliki kisaran 17-25 tahun yaitu sebanyak 26 orang (43,3\%), 26-30 tahun yaitu sebanyak 15 orang (25\%), dan 31-35 tahun sebanyak 19 orang (31,7\%). Dari distribusi responden berdasarkan usia tersebut, terlihat bahwa mayoritas responden pengguna jasa Rumah Laundry berada pada kisaran usia 17-25 tahun. Hal ini disebabkan karena konsumen yang berusia 17-25 tahun adalah konsumen yang sudah mempunyai penghasilan sendiri dan belum menikah sehingga mereka lebih banyak melakukan kesibukan pada aktifitas yang tidak berhubungan dengan pekerjaan rumah tangga seperti mencuci dan memasak.

\section{Karakteristik Responden Berdasarkan Pekerjaan}

Hasil penelitian yang dilakukan dengan jumlah 60 responden, diperoleh karakteristik responden berdasarkan pekerjaan yang terlihat dalam Gambar 4 berikut ini:

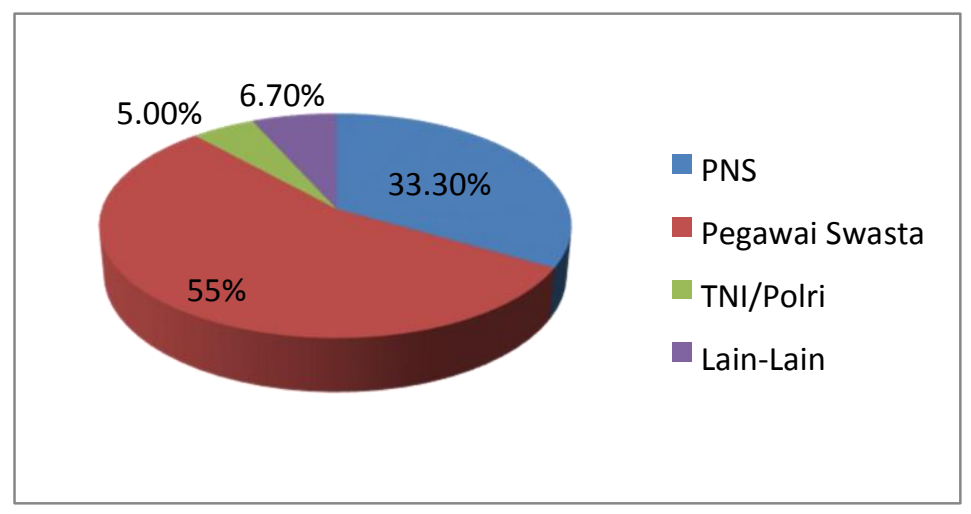

Gambar 4. Karakteristik Responden Berdasarkan Pekerjaan

Berdasarkan pekerjaan, tergambar bahwa dari 60 orang responden yang menggunakan jasa Rumah Laundry secara berturut-turut berfroresi sebagai pegawai swasta sebanyak 33 orang (55\%), PNS sebanyak 20 orang (33,3\%), TNI/Polri sebanyak 3 orang (5\%), lain-lain sebanyak 4 orang $(6,7 \%)$. Dari distribusi responden berdasarkan pekerjaan, terlihat bahwa mayoritas responden pengguna jasa Rumah Laundry mempunyai pekerjaan sebagai pegawai swasta, seperti yang terlihat pada gambar 5.3 diatas. Hal ini disebabkan karena sebagian besar pegawai swasta mempunyai kesibukan yang tidak menentu dikarenakan tambahan jam kerja dari setiap instansi yang menjadi tempat mereka mengabdi, hal ini paling sering dialami oleh pegawai swasta yang bekerja pada perusahaan finance seperti bank, adira, fif dan perusahaan lembaga keuangan lainnya, yang pada awal bulan dan akhir bulan mempunyai kesibukan rutin, sehingga waktu yang seharusnya mereka gunakan untuk menyelesaikan pekerjaan rumah seperti mencuci tersitah dengan tambahan jam kerja dari perusahaan mereka. 


\section{Karakteristik Responden Berdasarkan Pendidikan}

Hasil penelitian yang dilakukan dengan jumlah 60 responden, diperoleh karakteristik responden berdasarkan tingkat pendidikan sebagaimana yang terlihat dalam Gambar 7 dibawah ini:

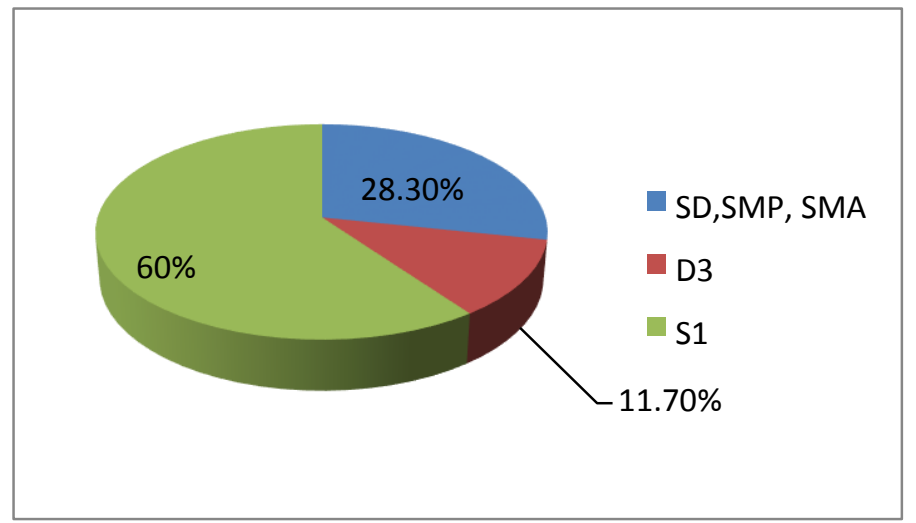

Gambar 5. Karakteristik Responden Berdasarkan Tingkat Pendidikan

Dari Gambar 5 diatas dapat diketahui bahwa dari segi tingkat pendidikan, responden yang menggunakan jasa Rumah Laundry memiliki tingkat pendidikan SD, SMP, SMA sebanyak 17 orang $(28,30 \%)$, D3 sebanyak 7 orang $(11,7 \%)$, S1 sebanyak 36 orang (60\%). Terlihat bahwa mayoritas responden yang menggunakan jasa Rumah Laundry memiliki tingkat pendidikan S1.

\section{Karakteristik Responden Berdasarkan Tingkat Pendapatan}

Hasil penelitian yang dilakukan dengan jumlah 60 responden diperoleh karakteristik responden berdasarkan tingkat pendapatan sebagaimana yang terlihat pada Gambar 6 dibawah ini:

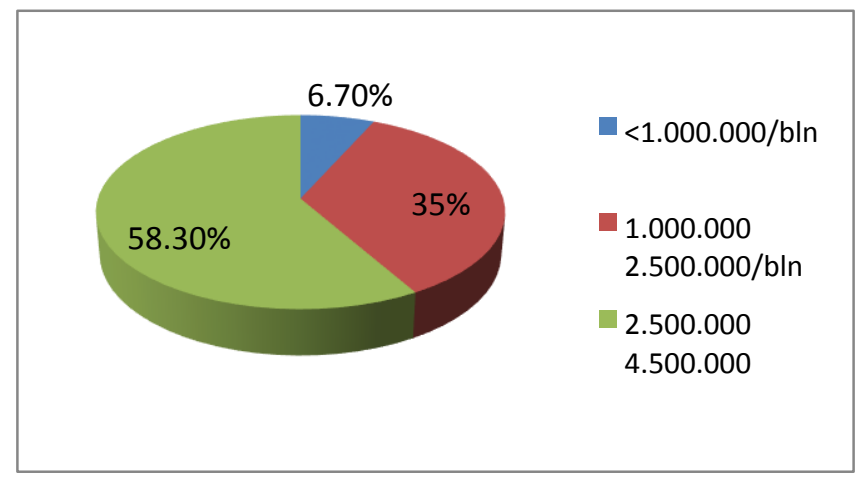

Gambar 6. Karakteristik Responden Berdasarkan Tingkat Pendapatan

Dari Gambar 6 diatas dapat diketahui bahwa dari segi pendapatan, rseponden yang menggunakan jasa Rumah Laundry memiliki tingkat pendapatan <Rp.1.000.000/bulan sebanyak 4 orang (6,60\%), Rp.1.000.000 - Rp. 2.500 .000 /bulan sebanyak 21 orang (35\%), Rp.2.500.000 Rp.4.500.000/ bulan sebanyak 35 orang $(58,3 \%)$. Terlihat bahwa mayoritas responden pengguna jasa Rumah Laundry memiliki pendapatan $2.500 .000-4.500 .000 /$ bulan.

\section{Deskriptif Variabel Penelitian}

Langkah berikutnya setelah semua data terkumpul yaitu melakukan tabulasi untuk membuat tingkatan tanggapan konsumen mengenai kepuasan konsumen berdasarkan variabel dari kualitas layanan yang terdiri dari Tangible, Empathy, Reliability, Responsiveness, Assurance, dan kepuasan konsumen. Dimana setiap butir pertanyaan akan diuji pada 60 responden. Seluruh tanggapan responden akan menentukan hasil dari penelitian. 


\section{Tanggapan Konsumen Mengenai Kualitas Layanan Pada Jasa Rumah Laundry}

Rumah Laundry melakukan berbagai upaya yang strategis dalam meningkatkan kualitas layanan agar kepuasan konsumen lebih meningkat. Hal ini dilakukan karena menghadapi situasi persaingan dari usaha-usaha laundry lainnya yang berlomba untuk memuaskan para konsumennya dengan cara memberikan mereka pelayanan yang sebaik mungkin.

Tabel 1. Tanggapan Responden Terhadap Variabel Kualitas Layanan

\begin{tabular}{|c|c|c|c|c|c|c|c|c|c|c|c|}
\hline \multirow{3}{*}{$\begin{array}{l}\text { Indikator } \\
\text { Tangible }\end{array}$} & \multicolumn{10}{|c|}{ Jawaban Responden } & \multirow{3}{*}{ Mean } \\
\hline & \multicolumn{2}{|c|}{ SS } & \multicolumn{2}{|c|}{$\mathrm{s}$} & \multicolumn{2}{|c|}{ RR } & \multicolumn{2}{|c|}{ IS } & \multicolumn{2}{|c|}{ STS } & \\
\hline & $\Sigma$ & $\%$ & $\Sigma$ & $\%$ & $\Sigma$ & $\%$ & $\Sigma$ & $\%$ & $\Sigma$ & $\%$ & \\
\hline $\begin{array}{l}\text { Xil } \\
\text { Rumah Laundry memiliki fasilitas mesin/ alat } \\
\text { pendukung yang lenghkap }\end{array}$ & 15 & 25 & 39 & 65 & 3 & 5 & 3 & 5 & - & - & 4.1000 \\
\hline $\begin{array}{l}\mathrm{X}_{1.2} \\
\text { Penampilan karyausan pada rumah laundry } \\
\text { mengutamakan kerapian } \\
\mathrm{X}_{1} .3\end{array}$ & 8 & 13.3 & 40 & 66.7 & 9 & 15.0 & 2 & 3.3 & 1 & 1.7 & 3.8667 \\
\hline $\begin{array}{l}\text { Rumah Laundry memiliki tampilan gedung yang baik } \\
\qquad \mathrm{X}_{1} .4\end{array}$ & 6 & 10.0 & 42 & 70.0 & 6 & 10.0 & 4 & 6.7 & 2 & 3.3 & 3.7667 \\
\hline Parkiran Yang Disediakan Memadai & 1 & 1.7 & 22 & 36.7 & 23 & 38.3 & 11 & 18.3 & 3 & 5.0 & 3.1167 \\
\hline Total Nilai Mean & & & & & & & & & & & 3.7125 \\
\hline $\begin{array}{c}\text { Empathy } \\
\mathrm{X}_{2.1}\end{array}$ & & & & & & & & & & & \\
\hline $\begin{array}{l}\text { Karyawan selalu memberikan perhatian lebil kepada } \\
\text { konoumen }\end{array}$ & 21 & 35.0 & 26 & 43.3 & 11 & 18.3 & 2 & 3.3 & - & - & 4.1000 \\
\hline $\begin{array}{l}\mathrm{X}_{2.2} \\
\text { Karyawan memberikan pelayanan yang myaman bagi } \\
\text { kousumen }\end{array}$ & 13 & 21.7 & 33 & 55.0 & 7 & 11.7 & 6 & 10.0 & 1 & 1.7 & 3.8500 \\
\hline Total Nillai Mean & & & & & & & & & & & 3.975 \\
\hline $\begin{array}{c}\text { Keliability } \\
\mathrm{X}_{\mathrm{H} .1}\end{array}$ & & & & & & & & & & & \\
\hline $\begin{array}{l}\text { Rumah Laundry selalu mampu menyediakan jasa sesuai } \\
\text { dengan apa yang dijanjikan } \\
\qquad \mathrm{X}_{\mathrm{J} .2}\end{array}$ & 15 & 25.0 & 35 & 58.3 & 9 & 15.0 & 1 & 1.7 & - & - & 4.0667 \\
\hline $\begin{array}{l}\text { Karyawan Rumah Laundry selalu tepat didelam } \\
\text { menangani masalah konsumen }\end{array}$ & 7 & 11.7 & 22 & 36.7 & 25 & 41.7 & 6 & 10.0 & - & - & 3.5000 \\
\hline Total Milai Mlean & & & & & & & & & & & 3.783 \\
\hline $\begin{array}{c}\text { Responsiveness } \\
\mathrm{X}_{4} \cdot 1\end{array}$ & & & & & & & & & & & \\
\hline $\begin{array}{l}\text { Kecepatan baryauran rumah laundry dalam merespon } \\
\text { permintaan pelanggan }\end{array}$ & 18 & 30.0 & 36 & $\infty 0.0$ & 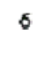 & 10.0 & - & - & - & - & 4.2000 \\
\hline $\begin{array}{l}\mathrm{X}_{4.2} \\
\text { Karyauran Rumnah Laundry selalu memberilan } \\
\text { informasi yang mudah dimengetti }\end{array}$ & 3 & 5.0 & 34 & 56.7 & 23 & 38.3 & - & - & - & - & 3.6667 \\
\hline Total Nilai Mean & & & & & & & & & & & 3.9333 \\
\hline $\begin{array}{c}\text { Assurance } \\
\mathrm{X}_{\mathrm{s} .1}\end{array}$ & & & & & & & & & & & \\
\hline $\begin{array}{l}\text { Karyawan Rumah Laundry selalu menjamin keamanan } \\
\text { palaian konsumen }\end{array}$ & 11 & 18.3 & 43 & 71.7 & 3 & 5.0 & 2 & 3.3 & 1 & 1.7 & 4.0167 \\
\hline $\begin{array}{c}\text { Xs.2 } \\
\text { Tingkat kejujuren pelayanan yang diberikan sangat baik }\end{array}$ & 20 & 33.3 & 29 & 48.3 & 9 & 15.0 & 2 & 3.3 & - & - & 4.1167 \\
\hline Total Nilai Mean & & & & & & & & & & & 4.0667 \\
\hline
\end{tabular}

Berdasarkan Tabel 1 diatas terhadap penilaian 60 responden pada variabel kualitas layanan indikator $\mathrm{X}_{1}$ (Tangible) jawaban responden terbanyak terdapat pada item setuju (S) yaitu pada indikator $\mathrm{X}_{1} .1$ terdapat 39 orang atau $65 \%, \mathrm{X}_{1} .240$ orang atau $66,7 \%, \mathrm{X}_{1} .342$ orang atau $70 \%$, dan indikator $\mathrm{X}_{1} .4$ terdapat 22 orang atau $22 \%$ dengan total nilai mean 3.7125 , hal ini disebabkan karena pada Rumah Laundry ini sendiri memiliki tampilan tata ruang yang terbuka sehingga konsumen dengan sendirinya bisa menilai dan melihat bahwa memang benar Rumah Laundry memiliki fasilitas alat pendukung yang lengkap, konsumen bisa secara langsung melihat proses pengerjaan pakaian yang telah mereka percayakan kepada Rumah Laundry, sehingga konsumen tidak perlu merasa khawatir dengan jaminan keamanan yang diberikan oleh karyawan Rumah Laundry.

Penilaian 60 responden pada indikator $\mathrm{X}_{2}$ (Empathy) jawaban responden terbanyak terdapat pada item setuju (S) yaitu pada indikator $X_{2 .} 1$ terdapat 26 orang atau $43,3 \%$ dan pada $X_{2 .} 2$ terdapat 33 
orang atau 55\% dengan total nilai mean 3.975, hal ini disebabkan karena konsumen merasa nyaman dengan perhatian perhatian dan pelayanan yang diberikan oleh karyawan Rumah Laundry melalui fasilitas yang ada dan komunikasi yang baik yang diberikan oleh karayawan Rumah Laundry.

Penilaian 60 responden pada indikator $\mathrm{X}_{3}$ (Reliability) jawaban responden terbanyak juga terdapat pada item setuju (S) yaitu pada indikator $X_{3 .} 1$ terdapat 35 orang atau 58,3\%, dan pada insikator $\mathrm{X}_{3.2}$ terdapat 22 orang atau 36,7\% dengan total nilai mean sebesar 3.783, hal ini disebabkan karena konsumen secara langsung bisa merasakan pelayanan yang baik dari pihakRumah Laundry melalui jasa yang disediakan yaitu pelayanan antar jemput pakaian konsumen dengan tarif harga yang terjangkau dan respon yang cepat didalam menangani keluhan konsumen.

Penilaian 60 responden pada indikator $\mathrm{X}_{4}$ (Responsiveness), jawaban responden terbanyak juga terdapat pada item setuju (S) yaitu sebanyak 36 orang $60 \%$ pada indikator $\mathrm{X}_{4} 1$ dan sebanyak 34 orang atau $56,7 \%$ pada indikator $\mathrm{X}_{4.2}$, dengan total nilai mean sebesar 3.0333. Hal ini disebabkan karena kedisiplinan waktu yang dimiliki dan telah diterapkan oleh karyawan Rumah Laundry didalam pengerjaan dan pengembalian pakaian sesuai dengan waktu yang telah disepakati bersama oleh konsumen dengan pihak laundry.

Penilaian 60 responden pada indikator $\mathrm{X}_{5}$ (Assurance), jawaban responden terbanyak terdapat pada item setuju (S) yaitu 43 orang atau $71,7 \%$ pada indikator $X_{5 .} 1$ dan 29 orang atau 48,3\% pada indikator $\mathrm{X}_{4} 2$ dengan total nilai mean 4.0667 , melihat persentase pilihan konsumen sangat besar hal ini berarti bahwa konsumen puas dengan kualitas jaminan yang diberikan oleh pihak Rumah Laundry, karena pengerjaan pakaian konsumen pada Rumah Laundry sistem pengerjaannya sudah sangat terstruktur setiap cucian masing-masing konsumen ditempatkan dalam box khusus sesuai dengan nama konsumen sehingga pakaian konsumen dijamin aman dan akan tertukar dengan pakaian konsumen yang lainnya, kemudian cucian yang mudah luntur dikerjakan secara terpisah.

\section{Variabel Kepuasan Konsumen}

Seorang konsumen yang merasakan puas terhadap kualitas layanan yang diterimanya adalah seseorang yang selalu menggunakan jasa dari penyedia jasa tersebut, dan memiliki sikap yang baik terhadap penyedia jasa tersebut dengan merekomendasikan teman atau kenalannya untuk menggunakan jasa laundry yang sama. Berikut ini adalah tanggapan responden mengenai kepuasan konsumen terhadap kualitas layanan yang disediakan oleh Rumah Laundry.

Tabel 2. Tanggapan Responden Terhadap Variabel Kepuasan Konsumen

\begin{tabular}{|c|c|c|c|c|c|c|c|c|c|c|c|}
\hline \multirow{3}{*}{ Indikator } & \multicolumn{10}{|c|}{ Jawaban Responden } & \multirow{3}{*}{ Mean } \\
\hline & \multicolumn{2}{|c|}{ SS } & \multicolumn{2}{|c|}{$\mathbf{S}$} & \multicolumn{2}{|c|}{ RR } & \multicolumn{2}{|c|}{ TS } & \multicolumn{2}{|c|}{ STS } & \\
\hline & $\Sigma$ & $\%$ & $\Sigma$ & $\%$ & $\Sigma$ & $\%$ & $\Sigma$ & $\%$ & $\Sigma$ & $\%$ & \\
\hline $\mathrm{Y}_{1.1}$ & & & & & & & & & & & \\
\hline $\begin{array}{c}\text { Saya akan tetap kembali ke Rumah Laundry } \\
\text { untuk menggunkan jasa yang disediakan } \\
\text { Y..2 }\end{array}$ & 25 & 41.7 & 35 & 58.3 & - & - & - & - & - & - & 4.4167 \\
\hline $\begin{array}{l}\text { Akan merekomendasikan kepada orang lain } \\
\text { untuk menjadi pelanggan }\end{array}$ & 4 & 6.7 & 51 & 85.0 & 5 & 8.3 & - & - & - & - & 3.9833 \\
\hline $\begin{array}{l}\qquad Y_{1.3} \\
\text { Kualitas layanan yang diberikan Rumah } \\
\text { Laundry sesuai dengan harapan }\end{array}$ & 30 & 50.0 & 29 & 48.3 & 1 & 1.7 & - & - & - & - & 4.4833 \\
\hline $\begin{array}{l}\qquad Y_{1-4} \\
\text { Kinerja yang diberikan Rumah Laundry } \\
\text { terhadap kualitas pelayanan konsumen sangat } \\
\text { baik }\end{array}$ & 36 & 60.0 & 23 & 38.3 & 1 & 1.7 & - & - & - & - & 4.5833 \\
\hline $\begin{array}{l}\qquad \text { Y1.5 } \\
\text { Pelayanan karyawan Rumah Laundry } \\
\text { memberikan kepuasan bagi konsumen } \\
\text { Total Nilai Mean }\end{array}$ & 30 & 50.0 & 28 & 46.7 & 2 & 3.3 & - & - & - & - & $\begin{array}{l}4.4667 \\
4.3866\end{array}$ \\
\hline
\end{tabular}

Berdasarkan Tabel 2 diatas dapat dilihat bahwa penilaian 60 responden terhadap variabel kepuasan konsumen dijelaskan bahwa indikator (Y1.1) yaitu konsumen akan tetap kembali ke Rumah Laundry untuk menggunakan jasa yang disediakan sebagian besar responden menjawab setuju sebanyak 35 orang atau 58,3\% dan responden yang menjawab sangat setuju sebanyak 25 oarang atau $41,7 \%$, dengan nilai mean sebesar 4.4167. Hal ini menunjukan bahwa responden menilai pelayanan dan jasa yang ditawarkan oleh Rumah Laundry sangat baik sehingga konsumen akan kembali untuk menggunakan jasa Rumah Laundry. 
Indikator (Y1.2) yaitu konsumen akan merekomendasikan jasa Rumah Laundry kepada orang lain untuk menggunakan jasa ini sebagian besar responden menjawab setuju sebanyak 51 orang atau $85 \%$, selanjutnya responden yang menjawab sangat setuju terdapat 4 orang atau $6,7 \%$, dan 5 orang atau $8,3 \%$ yang menjawab ragu-ragu, dengan nilai mean 3.9833. Hal ini menunjukan bahwa responden akan merekomendasikan jasa Rumah Laundry kepada orang lain untuk menggunakan jasa tersebut. Indikator (Y1.3) yaitu kualitas layanan yang diberikan Rumah Laundry sudah sesuai dengan harapan konsumen sebagian besar responden menjawab sangat setuju sebanyak 30 orang atau 50\%, responden yang menjawab setuju sebesar 29 orang atau $48,3 \%$, dan 1 orang atau 1,7\% responden yang menjawab ragu-ragu, dengan nilai mean 4.4833. Hal ini menunjukan bahwa penilaian responden terhadap kualitas layanan yang diberikan Rumah Laundry sangat baik dan sesuai dengan harapan konsumen.

Indikator (Y1.4) yaitu kinerja yang diberikan Rumah Laundry terhadap kualitas pelayanan konsumen sangat baik sebagian besar responden menjawab sangat setuju sebanyak 36 orang atau $60 \%$, responden yang menjawab setuju sebanyak 23 orang atau $38,3 \%$, dan 1 orang atau $1,7 \%$ responden menjawab ragu-ragu, dengan nilai mean 4.5833. Hal ini menunujukan bahwa kinerja yang diberikan oleh Rumah Laundry sangat baik. Indikator (Y1.5) yaitu pelayanan yang diberikan karyawan Rumah Laundry memberikan kepuasan bagi konsumen sebagian besar responden menjawab sangat setuju sebanyak 30 orang atau $50 \%$, selanjutnya responden yang menjawab setuju sebanyak 28 orang atau $46,7 \%$, dan 2 orang atau 3,3\% yang menjawab ragu-ragu, dengan nilai mean sebesar 4.4667. Hal ini menunujukan bahwa konsumen Rumah Laundry sudah sangat puas terhadap kualitas layanan yang diberikan oleh Rumah Laundry.

\section{HASIL DAN PEMBAHASAN \\ Hasil Analisis Regresi Linear Berganda}

Model analisis regresi linear berganda digunakan untuk mengetahui pengaruh kualitas layanan (Tangibles, Empathy, Reliability, Responsiveness, Assurance) terhadap kepuasan konsumen. Dalam menjawab permasalahan dan menguji hipotesis dalam penelitian ini digunakan alat analisis statistik regresi linear berganda (Multiple Linear Regresion) dengan menggunakan SPPS 16,0. Selanjutnya dapat dilihatpada Tabel 7 berikut ini:

\begin{tabular}{|c|c|c|c|c|c|}
\hline & \multirow{2}{*}{ Model } & \multicolumn{2}{|c|}{$\begin{array}{l}\text { Unstandardized } \\
\text { Coefficients }\end{array}$} & \multirow{2}{*}{$\begin{array}{c}\text { Standardized } \\
\text { Coefficients } \\
\text { Beta }\end{array}$} & \multirow{2}{*}{ Sig } \\
\hline & & B & Std. Error & & \\
\hline \multirow{9}{*}{$\begin{array}{l}\mathrm{R} \\
\mathrm{A} \\
\mathrm{M}\end{array}$} & (Constant) & 3.255 & .527 & & .000 \\
\hline & Bukti Fisik & .181 & .068 & .259 & .011 \\
\hline & Empati & .155 & .043 & .363 & .001 \\
\hline & Kehandalan & .182 & .051 & .379 & .001 \\
\hline & Daya Tanggap & -.374 & .065 & -.574 & .000 \\
\hline & Jaminan & .148 & .056 & .290 & .010 \\
\hline & uare $\left(\mathrm{R}^{2}\right)$ & & $=0.500$ & F-Hitung & $=10.799$ \\
\hline & isted R Square & & $=0.454$ & Konstanta & $=3.255$ \\
\hline & fiple R & & $=0.707^{\mathrm{a}}$ & Sig.F & $=0.000$ \\
\hline
\end{tabular}

Sumber: Hasil Pengolahan Data Koesioner

Hasil analisis regresi linear berganda dalam Tabel 3 diatas, kemudian dimasukkan kedalam model persamaan regresi linear berganda berikut:

$$
Y=3.255+0,181 X_{1}+0,155 X_{2}+0,182 X_{3}-, 374 X_{4}+0,148 X_{5}
$$

Berdasarkan regresi linear berganda tersebut, dapat dijelaskan sebagai berikut:

1. Nilai konstanta a adalah 3.255 yang menunjukkan bahwa variabel bukti fisik, empati, kehandalan, daya tanggap dan jaminan $\left(X_{1}, X_{2}, X_{3}, X_{4}\right.$ dan $\left.X_{5}\right)$ berpengaruh positif terhadap variabel kepuasan konsumen (Y). Berarti jika variabel bukti fisik, empati, kehandalan, daya tanggap dan jaminan berubah/konstan $\left(\mathrm{X}_{1}, \mathrm{X}_{2}, \mathrm{X}_{3}, \mathrm{X}_{4}\right.$ dan $\left.\mathrm{X}_{5}=0\right)$ maka kepuasan konsumen akan meningkat sebesar 3.255 .

2. Nilai koefisien regresi $b_{1}$ adalah 0,181 yang menunjukkan bahwa variabel bukti fisik $\left(X_{1}\right)$ berpengaruh positif terhadap kepuasan anggota. Berarti jika kehandalan ditingkatkan kearah yang 
lebih baik sedangkan empati, kehandalan, daya tanggap dan jaminan tidak berubah/konstan $\left(\mathrm{X}_{2}\right.$, $\mathrm{X}_{3}, \mathrm{X}_{4}$ dan $\mathrm{X}_{5}=0$ ) maka kepuasan konsumen akan meningkat sebesar satu satuan.

3. Nilai koefisien regresi $b_{2}$ adalah 0,155 yang menunjukkan bahwa variabel empati $\left(X_{2}\right)$ berpengaruh positif terhadap kepuasan anggota. Berarti jika empati ditingkatkan kearah yang lebih baik, sedangkan bukti fisik, kehandalan, daya tanggap dan jaminan tidak berubah/konstan $\left(\mathrm{X}_{1}, \mathrm{X}_{3}, \mathrm{X}_{4}\right.$ dan $\left.\mathrm{X}_{5}=0\right)$ maka kepuasan konsumen akan meningkat sebesar satu satuan.

4. Nilai koefisien regresi $b_{3}$ adalah 0,182 yang menunjukkan bahwa variabel kehandalan $\left(X_{3}\right)$ berpengaruh positif terhadap kepuasan konsumen. Berarti jika kehandalan ditingkatkan kearah yang lebih baik, sedangkan bukti fisik, empati, daya tanggap dan jaminan tidak berubah/konstan $\left(X_{1}, X_{2}, X_{4}\right.$ dan $\left.X_{5}=0\right)$ maka kepuasan konsumen akan meningkat sebesar satu satuan.

5. Nilai koefisien regresi $\mathrm{b}_{4}$ adalah,- 374 yang menunjukkan bahwa variabel daya tanggap $\left(\mathrm{X}_{4}\right)$ berpengaruh negatif terhadap kepuasan konsumen. Berarti jika variabel independen lain nilainya tetap dan daya tanggap $\left(\mathrm{X}_{4}\right)$ mengalami kenaikan $10 \%$ maka kepuasan konsumen $(\mathrm{Y})$ akan mengalami penurunan sebesar 0.374 . Koefisien negatif artinya terjadi hubungan negatif antara daya tanggap dan kepuasan konsumen $(\mathrm{Y})$. Jika daya tanggap $\left(\mathrm{X}_{4}\right)$ naik maka kepuasan konsumen menurun.

6. Nilai koefisien regresi $b_{5}$ adalah 0,148 yang menunjukkan bahwa variabel jaminan $\left(X_{5}\right)$ berpengaruh positif terhadap kepuasan konsumen. Berarti jika jaminan ditingkatkan kearah yang lebih baik sedangkan bukti fisik, empati, kehandalan, dan daya tanggap tidak berubah/konstan $\left(X_{1}, X_{2}, X_{3}\right.$ dan $\left.X_{4}=0\right)$ maka kepuasan anggota akan meningkat sebesar satu satuan.

Nilai koefisien korelasi (Multiple R) dalam tabel regresi linier berganda diatas sebesar 0.707 yang menunjukkan tingkat keeratan hubungan variabel bukti fisik, empati, kehandalan, daya tanggap, dan jaminan dengan variabel kepuasan konsumen. Nilai ini menunjukkan bahwa variabel bukti fisik, empati, kehandalan, daya tanggap, dan jaminan memiliki hubungan yang kuat dengan kepuasan konsumen. Berarti peningkatan bukti fisik, empati, kehandalan, daya tanggap, dan jaminan akan menyebabkan peningkatan yang besar terhadap kepuasan konsumen.

Sementara nilai koefisien determinasi (Adjusted $R$ Square) yang diperoleh adalah 0.500 . Nilai ini menunjukkan bahwa perubahan pada bukti fisik, empati, kehandalan, daya tanggap dan jaminan akan mempengaruhi 50,0\% kepuasan konsumen sedangkan sisanya yang sebesar 50,0\% dipengaruhi oleh variabel-variabel lain yang tidak diteliti.

\section{Pengujian Hipotesis Pertama (Uji Simultan/Uji F)}

Pengujian hipotesis pertama yaitu untuk mengetahui pengaruh secara simultan antara Tangibles, Empathy, Reliability, Responsiveness, Assurance terhadap kepuasan konsumen menggunakan jasa Rumah Laundry dengan taraf signifikan 0,05 (5\%) maka untuk lebih jelasnya dapat dilihat pada Tabel 4 berikut ini:

Tabel 4. Hasil Uji Simultan (Uji F)

\begin{tabular}{llccccc}
\hline & Model & Sum of Squares & Df & Mean Square & F & Sig. \\
\hline 1 & Regresion & 3.554 & 5 & .711 & 10.799 & $.000^{2}$ \\
& Residual & 3.555 & 54 & .066 & & \\
Total & 7.109 & 59 & & & \\
\hline
\end{tabular}

Sumber: Hasil Pengolahan Data Koesioner

Berdasarkan perhitungan menunjukan bahwa angka F-hitung sebesar 10.799 dengan tingkat signifikan $0,000<$ a 0,05. Maka Ho ditolak dan Ha diterima. Artinya variabel Bukti Fisik, Empati, Kehandalan, Daya Tanggap dan Jaminan secara serempak berpengaruh terhadap kepuasan konsumen menggunakan jasa Rumah Laundry di Kecamatan Palu Selatan.

\section{Pengujian Hipotesis Secara Parsial (Uji T)}

Pengujian hipotesis secara parsial digunakan untuk menguji pengaruh dari masing-masing variabel bebas secara parsial terhadap variabel (Y), berikut penjelasan untuk masing-masing hasil Ujit untuk setiap variabel independen: 


\section{Pengaruh Variabel Bukti Fisik $\left(X_{I}\right)$ Terhadap Kepuasan Konsumen.}

Berdasarkan Tabel 4 diatas diketahui bahwa besarnya probabilitas signifikansi variabel bukti fisik $\left(\mathrm{X}_{1}\right)$ adalah $0,011<$ taraf signifikan yang disyaratkan $\mathrm{a}=0,05$. Dengan demikian bahwa variabel bukti fisik dalam penelitian ini secara parsial berpengaruh positif atau signifikan terhadap kepuasan konsumen menggunakan jasa Rumah Laundry di Kecamatan Palu Selatan. Maka dapat disimpulkan Ho ditolak dan Ha diterima.

\section{Pengaruh Variabel Empati $\left(\mathrm{X}_{2}\right)$ Terhadap Kepuasan Konsumen.}

Berdasarkan Tabel 4 diatas diketahui bahwa besarnya probabilitas signifikansi variabel bukti fisik $\left(\mathrm{X}_{2}\right)$ adalah $0,001<$ taraf signifikan yang disyaratkan $\mathrm{a}=0,05$. Dengan demikian bahwa variabel Empati dalam penelitian ini secara parsial berpengaruh positif atau signifikan terhadap kepuasan konsumen menggunakan jasa Rumah Laundry di Kecamatan Palu Selatan. Maka dapat disimpulkan Ho ditolak dan Ha diterima.

\section{Pengaruh Variabel Kehandalan $\left(X_{3}\right)$ Terhadap Kepuasan Konsumen.}

Berdasarkan Tabel 4 diatas diketahui bahwa besarnya probabilitas signifikansi variabel bukti fisik $\left(\mathrm{X}_{3}\right)$ adalah $0,001<$ taraf signifikan yang disyaratkan $\mathrm{a}=0,05$. Dengan demikian bahwa variabel kehandalan dalam penelitian ini secara parsial berpengaruh positif atau signifikan terhadap kepuasan konsumen menggunakan jasa Rumah Laundry di Kecamatan Palu Selatan. Maka dapat disimpulkan Ho ditolak dan Ha diterima.

\section{Pengaruh Variabel Tanggap $\left(X_{4}\right)$ Terhadap Kepuasan Konsumen.}

Berdasarkan Tabel 4 diatas diketahui bahwa besarnya probabilitas signifikansi variabel bukti fisik $\left(\mathrm{X}_{4}\right)$ adalah $0,000<$ taraf signifikan yang disyaratkan $\mathrm{a}=0,05$. Dengan demikian bahwa variabel daya tanggap dalam penelitian ini secara parsial berpengaruh positif atau signifikan terhadap kepuasan konsumen menggunakan jasa Rumah Laundry di Kecamatan Palu Selatan. Maka dapat disimpulkan Ho ditolak dan Ha diterima.

\section{Pengaruh Variabel Jaminan $\left(X_{5}\right)$ Terhadap Kepuasan Konsumen.}

Berdasarkan Tabel 4 diatas diketahui bahwa besarnya probabilitas signifikansi variabel bukti fisik $\left(X_{5}\right)$ adalah $0,010<$ taraf signifikan yang disyaratkan $a=0,05$. Dengan demikian bahwa variabel jaminan dalam penelitian ini secara parsial berpengaruh positif atau signifikan terhadap kepuasan konsumen menggunakan jasa Rumah Laundry di Kecamatan Palu Selatan. Maka dapat disimpulkan Ho ditolak dan Ha diterima.

\section{Pembahasan Hasil Penelitian Pengaruh Bukti Fisik Terhadap Kepuasan Konsumen}

Lupiyoadi (2013), menerapkan bukti fisik adalah kemampuan suatu perusahaan dalam menunjukan eksistensi kepada pihak eksternal. Penampilan dan kemampuan sarana dan prasarana fisik perusahaan dan keadaan lingkungan sekitarnya adalah bukti nyata dari layanan yang diberikan oleh pembeli jasa yang meliputi fasilitas fisik (gedung, lahan parkir dan lain sebagainya), perlengkapan dan peralatan yang dipergunakan (teknologi), serta penampilan pegawainya.

Dari hasil perhitungan statistik diperoleh nilai koefisien regresi bukti fisik 0,181 artinya terdapat hubungan yang positif antara variabel bukti fisik dengan kepuasan konsumen atau dengan kata lain setiap perubahan pada variabel bukti fisik maka kepuasan konsumen akan berubah dengan persentase perubahan nilai statistik sebesar 0,181 , sedangkan nilai signifikansi variabel bukti fisik adalah $0,011<0,05$. Hal ini memberi arti bahwa variabel bukti fisik dalam penelitian ini mempunyai pengaruh yang signifikan terhadap kepuasan konsumen menggunakan jasa Rumah Laundry sebagai jasa pencucian pakaian dan barang-barang sejenisnya. Hal ini juga dikarenakan Rumah Laundry memiliki fasilitas mesin/ alat pendukung yang lengkap dan memiliki tampilan gedung yang baik.

\section{Pengaruh Empati Terhadap Kepuasan Konsumen}

Empati menurut Tjiptono (2008) adalah kemudahan dalam melakukan Hubungan, komunikasi yang baik, perhatian pribadi dan memahami kebutuhan para pelanggan. 
Dari hasil perhitungan statistik diperoleh nilai koefisien regresi empati 0,155 artinya terdapat hubungan yang positif antara variabel empati dengan kepuasan konsumen atau dengan kata lain setiap perubahan pada variabel empati maka kepuasan konsumen akan berubah dengan persentase perubahan nilai statistik sebesar 0,155 , sedangkan nilai signifikansi variabel empati adalah $0,001<0,05$. Hal ini memberi arti bahwa variabel empati dalam penelitian ini mempunyai pengaruh yang signifikan terhadap kepuasan konsumen menggunakan jasa Rumah Laundry sebagai jasa pencucian pakaian dan barang-barang sejenisnya.

\section{Pengaruh Kehandalan Terhadap Kepuasan Konsumen}

Tjiptono (2008) mendefinisikan kehandalan adalah mencakup dua hal pokok, yaitu konsistensi kerja (performance) dan kemampuan untuk dipercaya (dependability). Hal ini berarti perusahaan memberikan jasanya secara tepat semenjak saat pertama (right the first time). Selain itu juga berarti bahwa perusahaan yang bersangkutan memenuhi janjinya, misalnya menyampaikan jasanya sesuai dengan jadwal yang disepakati.

Berdasarkan hasil perhitungan statistik untuk variabel kehandalan diperoleh nilai koefisien regresi kehandalan 0,182 artinya terdapat hubungan yang positif antara variabel kehandalan dengan kepuasan konsumen atau dengan kata lain setiap perubahan pada variabel kehandalan maka kepuasan konsumen akan berubah dengan persentase perubahan nilai statistik sebesar 0,182 , sedangkan nilai signifikansi variabel kehandalan adalah $0,001<0,05$. Hal ini memberi arti bahwa variabel kehandalan dalam penelitian ini mempunyai pengaruh yang signifikan terhadap kepuasan konsumen menggunakan jasa Rumah Laundry sebagai jasa pencucian pakaian dan barang-barang sejenisnya.

\section{Pengaruh Daya Tanggap Terhadap Kepuasan Konsumen}

Menurut Lupiyoadi (2013), daya tanggap adalah suatu kemampuan untuk membantu dan memberikan layanan yang cepat (responsif) dan tepat kepada pelanggan, dengan penyampaian informasi yang jelas. Membiarkan konsumen menunggu tanpa adanya suatu alasan yang jelas menyebabkan persepsi yang negatif dalam kualitas layanan.

Berdasarkan hasil perhitungan statistik untuk variabel daya tanggap diperoleh nilai koefisien regresi daya tanggap $-0,374$ artinya terdapat hubungan yang negatif antara variabel daya tanggap dengan kepuasan konsumen atau dengan kata lain apabila variabel daya tanggap ditingkatkan maka kepuasan konsumen akan menurun sebesar satu satuan, sedangkan jika dilihat pada nilai signifikansi variabel daya tanggap adalah $0,000<0,05$ yang artinya variabel daya tanggap berpengaruh signifikan terhadap kepuasan konsumen. Dengan demikian dapat disimpulkan bahwa varabel daya tanggap memiliki pengaruh terhadap kepuasan konsumen tetapi terdaoat hubungan yang negatif antara variabel daya tanggap dengan kepuasan konsumen atau dapat dikatakan hubungan kedua variabel sangat kuat, signifikan tetapi tidak searah.

\section{Pengaruh Jaminan Terhadap Kepuasan Konsumen}

Menurut Lupiyoadi (2013), jaminan adalah pengetahuan, kesopansantunan dan kemampuan para pegawai perusahaan untuk menumbuhkan rasa percaya para pelanggan kepada perusahaan. Terdiri dari beberapa komponen antara lain komunikasi, krediabilitas, keamanan, kompetensi dan sopan santun.

Berdasarkan hasil perhitungan statistik untuk variabel jaminan diperoleh nilai koefisien regresi jaminan 0,148 artinya terdapat hubungan yang positif antara variabel kehandalan dengan kepuasan konsumen atau dengan kata lain apabila variabel jaminan ditingkatkan maka kepuasan konsumen akan meningkat sebesar 0,148 , sedangkan nilai signifikansi variabel jaminan adalah 0,010

$<0,05$. Hal ini memberi arti bahwa variabel jaminan dalam penelitian ini mempunyai pengaruh yang signifikan terhadap kepuasan konsumen menggunakan jasa Rumah Laundry sebagai jasa pencucian pakaian dan barang-barang sejenisnya.

\section{Variabel yang Paling Dominan yang memengaruhi Kepuasan Konsumen}

Untuk melihat variabel yang paling brpengaruh dapat dilihat pada nilai Unstandarized Coefficient. Pada tabel regresi nilai beta yang paling tinggi ada pada variabel kehandalan $\left(\mathrm{X}_{3}\right)$ yaitu sebesar 0,182. Hal ini menandakan bahwa diantara variabel independen lainnya kehandalan menjadi salah satu tolak ukur para pelanggan dalam hal kepuasan memilih jasa Rumah Laundry sebagai jasa 
pencucian pakaian dan barang sejenisnya. Berdasarkan hasil observasi maka peneliti mendapatkan realita bahwa sebagian besar responden sangat senang dengan kehandalan dalam menyediakan jasa dan selalu tepat didalam menangani masalah dan keluhan konsumen.

\section{KESIMPULAN DAN SARAN}

\section{Kesimpulan}

Dari hasil penelitian diatas dapatlah ditarik kesimpulan sebagai berikut:

1. Variabel kualitas layanan yang terdiri dari: Bukti Fisik (Tangibles), Empati(Empathy), Kehandalan (Reliability), Daya Tanggap (Responsiveness) dan Jaminan (Assurance ) secara serempak berpengaruh signifikan terhadap kepuasan konsumen menggunakan jasa Rumah Laundry di Kecamatan Palu Selatan.

2. Variabel Bukti Fisik $\left(\mathrm{X}_{1}\right)$ berpengaruh signifikan terhadap kepuasan konsumen menggunakan jasa Rumah Laundry di Kecamatan Palu Selatan.

3. Variabel Empati $\left(\mathrm{X}_{2}\right)$ berpengaruh signifikan terhadap kepuasan konsumen menggunakan jasa Rumah Laundry di Kecamatan Palu Selatan.

4. Variabel Kehandalan $\left(X_{3}\right)$ berpengaruh signifikan terhadap kepuasan konsumen menggunakan jasa Rumah Laundry di Kecamatan Palu Selatan.

5. Variabel Daya Tanggap $\left(\mathrm{X}_{4}\right)$ berpengaruh negatif terhadap kepuasan konsumen menggunakan jasa Rumah Laundry di Kecamatan Palu Selatan.

6. Variabel Jaminan $\left(\mathrm{X}_{5}\right)$ berpengaruh signifikan terhadap kepuasan konsumen menggunakan jasa Rumah Laundry di Kecamatan Palu Selatan.

Dapat disimpulkan bahwa kualitas layanan yang terdiri dari Bukti Fisik (Tangibles), Empati(Empathy), Kehandalan (Reliability), Daya Tanggap (Responsiveness) dan Jaminan (Assurance) yang ada di Rumah Laundry yang berpengaruh paling signifikan terhadap kepuasan konsumen yaitu variabel X3 (kehandalan/reliability), karena dapat dilihat bahwa pihak Rumah Laundry mampu menyediakan jasa sesuai dengn apa yang dijanjikan dan karyawan Rumah Laundry selalu tepat dalam menangani setiap keluhan dan masalah konsumen.

\section{Saran}

Berdasarkan kesimpulan yang dapat ditarik dari uraian dan pembahasan pada bab-bab sebelumnya maka penulis memberikan saran yang mungkin bermanfaat untuk meningkatkan kualitas layanan pada jasa Rumah Laundry sebagai berikut:

1. Bagi Rumah Laundry

Rumah Laundry harus memperhatikan hal-hal yang berkaitan dengan penigkatan kualitas layanan baik dari kenyamanan konsumen menggunakan jasa Rumah Laundry, utamanya bagi setiap karyawan Rumah Laundry didalam merespon permintaan pelanggan yang menngunakan jasa tersebut dan harus selalu memberikan informasi yang mudah dimengerti oleh setiap pelanngan agar kedepannya mampu memberikan pelayanan yang baik dari yang sudah ada karena melihat begitu banyaknya perusahaan-perusahaan jasa laundry yang lain.

2. Bagi peneliti lain

Berdasarkan koefisien determinasi diatas, diperlukan penelitian lain yang mampu menjelaskan variabel-variabel lain yang mempengaruhi kepuasan konsumen.

\section{REFERENSI}

Ghozali, I. (2005). Aplikasi Analisis Multivariate Dengan Program Spss, Edisi Ketiga, Badan Penerbit Universitas Di Ponegoro, Semarang.

Lovelock, Christopher, Jochen, W. \& Jacky, M., (2010). Pemasaran Jasa (Manusia, Teknologi, Strategi) edisi ketujuh jilid 2. Penerbit Erlangga.

Lupiyoadi, R. (2001). Manajmen Pemasaran Jasa (Teori dan Praktik). Jakarta: Salemba 4.

Sugiyono. (2013). Metode Penelitian Bisnis, Cetakan ke-17. Penerbit ALFABETA : Bandung.

Sugiyono. (2014). Metode Penelitian Administrasi, Cetakan Ke-22. Penerbit ALFABETA : Bandung.

Sugiyono. (2014). Metode penelitian kuantitatif Kualitatif dan R\&D, Alfabeta, Bandung.

Tjiptono, F., dkk. (2008). Pemasaran Strategik, edisi 1. Penerbit C.V Andi Offest (Penerbit ANDI) : Yogyakarta.

Tjiptono, F. (2002). Manajemen Jasa, CV. Andi Offset, Yogyakarta. 